Diabetologia 9, 499-504 (1973)

(C) by Springer-Verlag 1973

\title{
Action of Insulin and Glucose on the Re-Esterification Rate of Free Fatty Acids in Isolated Human Fat Cells*
}

\author{
H.-J. Lisch, S. Sailer, F. Sandhofer, W. Schennach and H. Braunsteiner \\ Medizinische Universitätsklinik and Chirurgische Universitätsklinik, A-6020 Innsbruck, Austria \\ Received: February 12, 1973, and in revised form: July 30, 1973
}

\begin{abstract}
Summary. In isolated human fat cells of the greater omentum and the mammary gland, the effect of glucose, fructose, and/or insulin was tested on the re-esterification rate of FFA measured by the balance method. It could be shown that in the absence of glucose no re-esterification activity was demonstrable. Glucose alone or fructose alone stimulated the re-esterification of FFA dose-dependently in isolated fat cells of the greater omentum, and to a minor degree in fat cells of the mammary gland.
\end{abstract}

Insulin had no effect on the re-esterification rate of FFA in the presence or absence of glucose or fructose, whereas it significantly stimulated the incorporation of glucose- $\mathrm{C}$ into $\mathrm{CO}_{2}$ and lipids. It is concluded that the re-esterification of FFA in human adipose tissue, at least in vitro, is mainly controlled by glucose without need for insulin.

Key words: Glucose, fructose, insulin, isolated fat cells, re-esterification of free fatty acids.
The release of tree fatty acids (FFA) by adipose tissue is modulated by the activity of two pathways, the hydrolysis of triglycerides to glycerol and FFA (lipolysis) and the re-esterification of FFA so produced. A previous paper dealt with the influence of insulin and glucose on the lipolysis in isolated human fat cells [29]. The purpose of the present work was to study the influence of insulin and glucose on the re-esterification rate of FFA. The re-esterification rate of FFA can be determined by the balance method of Vaughan [39]. This method is based on the simultaneous measurement of the release of glycerol and FFA in the incubation medium plus the adipose tissue and rests on three assumptions: (a) Glycerol is not metabolized, i.e. phosphorylated, to any significant extent, (b) glycerol is formed exclusively by the splitting of triglycerides and does not derive from the alpha-glycerophophate pool, and (c) there is no significant formation of partial glycerides. In spite of the fact that rat adipose tissue glycerokinase activity can actually account for a considerable deficit of glycerol $(14-15 \%)$ during a three hour incubation $[19,25,34]$, it was recently shown, that in human adipose tissue glycerokinase activity phosphorylates only $2-3.5 \%$ of the released glycerol [24]. Thanks to these results one can assume that the method of Vaughan can be safely applied to human adipose tissue, while it might now be questionable to apply it to rat adipose tissue. Assumption (b) is supported by the findings of Björntorp [3], who found the incorporation of label from $1{ }^{-14} \mathrm{C}$-glucose into the released glycerol to be insignificant. Assumption (c) is substantiated by the fact that in our experiments a negative re-esterification rate could not be observed under any condition (see results). This applies at least to isolated human fat cells, but not to homogenates of human adipose tissue [27].

* Preliminary results of this investigation were presented at the 6 th Annual Meeting of the EASD, Warsaw, 1970 .
Compared with isotopic methods for the assessment of the esterification of FFA by adipose tissue, i. e. the measurement of the incorporation of labelled glucose or labelled palmitate into triglycerides, the nonisotopic balance method has been proven to be more reliable, because the problem of dilution of labelled substrate by endogenous unlabelled metabolites can be avoided [26]. Moreover, it has elearly been shown that there exist several pools of FFA within adipose tissue, with different specific activities [38], which renders the interpretation of the results on the uptake of labelled palmitate even more difficult.

In rat adipose tissue, the stimulating action of glucose on the re-esterification rate of FFA and the additional effect of insulin thereon is well-established. In human adipose tissue, however, reports on the action of glucose and/or insulin on the re-esterification rate of FFA are rare. Glucose seems to possess a slight stimulating action at abnormally high concentrations [5]. Insulin exerts a moderate stimulation of the reesterification of FFA in the absence of glucose and a marked increase in the presence of glucose [5].

Since the release of FFA from adipose tissue constitutes one of the major pathways of the energy supply to the organism and this release is controlled, besides lipolysis, by the re-esterification rate of FFA, experiments have been undertaken to investigate the influence of insulin and/or glucose and/or fructose on the re-esterification rate of FFA in isolated human fat cells.

\section{Materials and Methods}

\section{Source of Adipose Tissue}

Adipose tissue was removed during operations under general anaesthesia with thiopental, nitrous oxide, halothane, and oxygen from the greater omentum and the mammary gland of patients of both 
sexes aged between 21 and 77 years. The relative body weight $\left(\frac{\text { average weight [37] }}{\text { actual weight }}\right) \pm S E M$ was $1.03 \pm 0.03$ (range: $0.71-1.50$ ). Operations were performed in the morning after an overnight fast of $15 \mathrm{~h}$. The preoperative medication consisted of morphine and atropine. During the operation the patients received, apart from the anaestheties, Ringer solution at a slow infusion rate.

The possibility of an effect of general anaesthesia on the re-esterification rate of FFA cannot be absolutely excluded. However, it has been demonstrated, that neither type of surgical procedure performed nor agents used for general anaesthesia influenced basal or stimulated lipolysis [22]. Therefore, it can be supposed that also the re-esterification of FFA remains unaltered by general anaesthesia. Moreover, all patients underwent the same type of general anaesthesia, which justifies comparisons made within special groups of these patients.

The patients suffered from gastric and duodenal ulcers, gastrie cancer, cholelithiasis, and mammary cancer. No patients had endocrine disorders, cancer cachexia, or experienced major stress or major blood loss.

Immediately after the excision, the adipose tissue was placed in Krebs Ringer bicarbonate buffer [35] at room temperature. During transport to the laboratory the buffer solution containing the adipose tissue was kept in a thermos bottle at $37^{\circ} \mathrm{C}$. Approximately 20 min after removal, the isolation of the fat cells was undertaken.

\section{Preparation of Isolated Fat Cells. Determination of Average Volume and Destruction Index of the Isolated Fat Cells}

The isolation of the fat cells from the adipose tissue was performed according to Rodbell [35] with some modifications [29]. The albumin used was Bovine Serum Albumin, Fraction V (Armour Pharmaceutical Company Ltd., Eastbourne, England; batch no. RM 2770 and RN 0970). Collagenase was obtained from Worthington Biochemical Corporation (Freehold, New Jersey, U.S. A.; batch no. $9 \mathrm{KC}$ and OCB). The experimental procedures for the determination of the average volume and of the destruction index of the isolated fat cells are described elsewhere [28]. It has been established previously, that the breakage of the fat cells during the incubation period is less than $15 \%$ and there is no difference in the breakage of small and large fat cells [28].

\section{Determination of the Re-Esterification Rate of FFA}

The determination of the re-esterification rate of FFA in isolated fat cells was performed using the balance method of Vaughan [39], which is based on the formula :
Re-esterified fatty acids ( $\mu$ moles/g triglyceride $/ \mathrm{h}$ ) $=$ released glycerol ( $\mu$ moles/g triglyceride $/ \mathrm{h}) \times 3$ minus released fatty acids ( $\mu$ moles/g triglyceride/h).

The formula applies to total FFA, i.e. medium plus cell FFA, which implies the determination of glycerol and FFA in the cell suspension (medium plus cells). The pipetting of the cell suspension was performed after a short shaking by hand to provide an equal distribation of the fat cells in the buffer medium.

The isolated fat cells were incubated for $1 \mathrm{~h}$ in Krebs Ringer bicarbonate buffer containing 4\% albumin $(\mathrm{w} / \mathrm{v})$ at $\mathrm{pH} 7.4$ in single uncapped polyethylene vials each containing $2.5 \mathrm{ml}$ of packed cells and $5 \mathrm{ml}$ albumin buffer in an atmosphere of $95 \%$ oxygen and $5 \%$ carbon dioxide using a Dubnoff metabolic shaker (100 cycles/min). Glucose and insulin were added to the fat cell suspension immediately before incubation without any preincubation. Glycerol was determined before and after the incubation period in $2 \mathrm{ml}$ aliquots of the same cell suspension sample (14, as adapted by 29) and expressed as umoles/g triglyceride/h. The triglyceride concentration was estimated by the method of Carlson [8]. $1 \mathrm{ml}$ of the fat cell suspension contained on an average $50-80 \mathrm{mg}$ triglycerides.

The determination of the release of FFA was carried out with an adapted method of Duncombe [10]: Immediately before and after the incubation period, $1 \mathrm{ml}$ aliquots of the same cell suspension sample were removed and treated with $5 \mathrm{ml}$ methanol, $10 \mathrm{ml}$ chloroform [13], and $15 \mathrm{ml} 0.2 \mathrm{M}$ sodium dihydrogenphosphate. The following day, $8 \mathrm{ml}$ aliquots of the chloroform phase were shaken with silicagel (silicic acid, 100 mesh, powder, from Mallinckrodt Chemical Works, St. Louis, U.S.A.) for 15 sec to remove traces of phospholipids from the extract; silicagel does not adsorb FFA. After a short period at room temperature, the silicagel sedimented and $2 \times 3 \mathrm{ml}$ of the chloroform extracts were transferred into glass tubes each containing $2.5 \mathrm{ml}$ of Duncombe's copper reagent. The release of FFA was calculated by the estimation of the difference of the FFA concentrations in the cell suspension between the start and the end of the incubation period and was expressed as $\mu$ moles/g triglyceride/h.

$1 \mathrm{~N}$ hydrochloric acid was used to clean the glass tubes [32], because detergents grossly interfere with the colour reaction.

\section{Determination of Incorporation of Glucose- $U-{ }^{14} C$ into $\mathrm{CO}_{2}$ and Lipids}

To exclude a possible destruction of the insulin receptor system of the fat cells by the isolation procedure, experiments have been undertaken to study the effect of insulin on the incorporation of labelled glucose into $\mathrm{CO}_{2}$ and lipids. $1 \mathrm{ml}$ of packed isolated fat cells were incubated together with $2 \mathrm{ml}$ of $4 \%$ albumin bicarbonate buffer containing unlabelled glucose and glucose-U_- ${ }^{14} \mathrm{C}(\mathrm{CFB}$, The Radiochemical Centre Amersham) to a final concentration of $0.1 \mathrm{mg} / \mathrm{ml}$ and 0.5 
$\mu \mathrm{Ci} / \mathrm{ml}$, respectively. Insulin was added achieving a final concentration of $1000 \mu \mathrm{U} / \mathrm{ml}$. The incubations were performed in duplicate polyethylene vials for $1 \mathrm{~h}$ using a metabolic shaker. ${ }^{14} \mathrm{CO}_{2}$ was estimated by the method of Rodbell [35]. For determination of ${ }^{14} \mathrm{C}$-lipids $1 \mathrm{ml}$ aliquots of the cell suspension were removed after the equilibration period for $\mathrm{CO}_{2}$ collection and treated with $5 \mathrm{ml}$ methanol, $10 \mathrm{ml}$ chloroform [13], and $15 \mathrm{ml}$ saline. The following day, $8 \mathrm{ml}$ of the chloroform phase

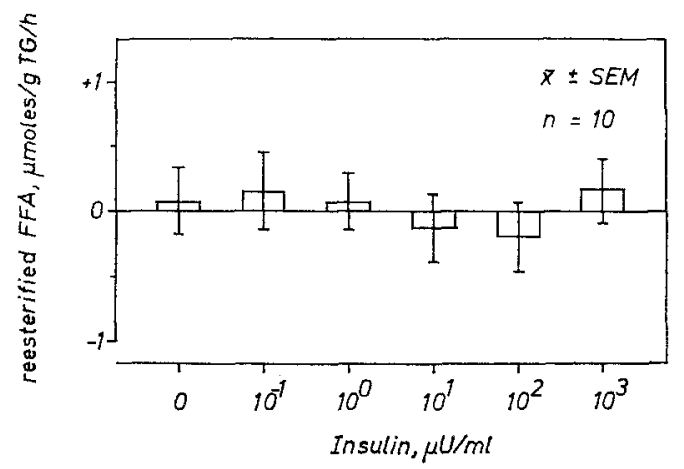

Fig. 1. Effect of insulin $(0.1-1000 \mu \mathrm{U} / \mathrm{ml})$ on the reesterification rate of FFA in isolated human omental fat cells. No glucose in the medium. The mean values of single determinations in 10 patients are indicated. The destruction index of the isolated fat cells was $0.75 \pm 0.07$ $($ mean \pm SEM $)$
The isolated fat cells of 6 patients undergoing the same type of general anaesthesia and the same types of operations as described before were studied: The basal glucose oxidation (mean value of 6 sets of duplicate determinations \pm SEM) was $48.1 \pm 13.6$ nmoles glucose/g triglyceride/h. This was stimulated by insulin to $64.4 \pm 21.2$, i.e. $128.6 \pm 7.8 \%$. The percent stimulation was significant at the 0.02 level.

$414.9 \pm 110.9$ nmoles glucose $/ g$ triglyceride $/ \mathrm{h}$ were incorporated into lipids. This was increased by insulin to $549.4 \pm 163.4$. i.e. $129.0 \pm 5.1 \%$. The percent stimulation was significant $(p<0.01)$.

\section{Results}

The rate of lipolysis and the antilipolytic effect of insulin was published elsewhere [29]. Insulin exerted an antilipolytic effect only on a high (stimulated) lipolysis. On the basis of our data, which we have obtained so far, no clear interrelationship between lipolysis and re-esterification rate of FFA could be shown. It has to be pointed out, however, that the measurement of the re-esterification rate of $\mathrm{FFA}$ was carried out only in isolated fat cells with a normal unstimulated lipolysis (average value of all investigated cases \pm SEM: $0.76 \pm 0.06$ umoles glycerol $/ g$ triglyceride $/ \mathrm{h}$; range: $0.23-\mathbf{1 . 4 8}$ ).
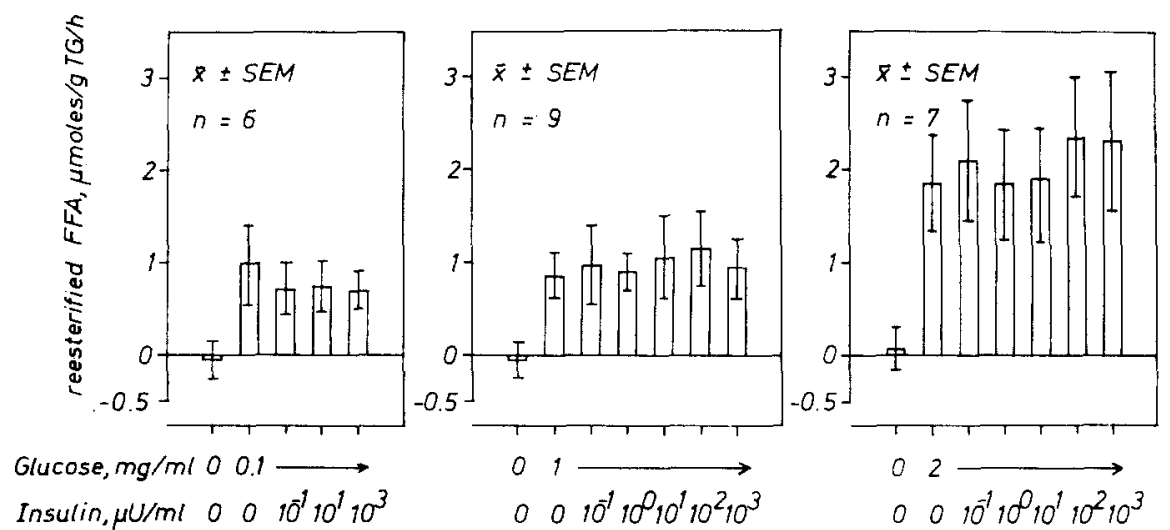

Fig. 2. Effects of glucose $(0.1,1$, and $2 \mathrm{mg} / \mathrm{ml})$ and glucose plus insulin $(0.1-1000 \mu \mathrm{U} / \mathrm{ml})$ on the re-esterification rate of FFA in isolated omental fat cells. The mean values of the calculated re-esterification rate (single determinations) in 3 different groups of patients are indicated. The fat cell destruction index \pm SEM was for the cases in the first rectangle $0.72 \pm 0.04$, in the second one $0.74 \pm 0.07$, and in the third one $0.71 \pm 0.12$

were aspirated and evaporated. The remaining lipids were dissolved in $10 \mathrm{ml}$ scintillation fluid consisting of $0.5 \% \quad 2,5$-diphenyloxazol and $0.03 \% \quad 1,4$-bis-2-(4methyl-5-phenyl-oxazolyl)-benzene in toluene and counted in a Packard liquid scintillation counter. Quenching was corrected by the internal standard method. The quantities of glucose converted to $\mathrm{CO}_{2}$ and lipids were calculated from the initial specific activity of the glucose in the medium and the quantity of radioactivity in the products. Results are expressed as nmoles of glucose per $g$ triglyceride in the cell suspension per hour.
Figure 1 demonstrates the action of insulin (Actrapid ${ }^{\circledR}$, Novo) on the re-esterification rate of FFA in human omental fat cells. It becomes evident, that without glucose in the medium there was no reesterification rate at all and that this was not changed in the presence of insulin at concentrations up to 1000 $u \mathrm{U} / \mathrm{ml}$.

The influence of glucose and insulin on the reesterification of FFA in isolated fat cells of the greater omentum is shown by Fig. $2.2 \mathrm{mg} / \mathrm{ml}(t=4.38, p<$ $0.01), 1 \mathrm{mg} / \mathrm{ml}(t=3.68, p<0.01)$, and as little as 0.1 $\mathrm{mg} / \mathrm{ml}$ glucose $(t=2.64, p<0.05)$ stimulated the re- 
esterification rate significantly. A dose-response relationship for glucose in the range of $0.1-2 \mathrm{mg} / \mathrm{ml}$ is suggested by the figure. In no instance $(0.1,1$, and 2 $\mathrm{mg} / \mathrm{ml}$ glucose) could a significant increase of the reesterification rate of FFA by the addition of insulin be observed.

Isolated fat cells of the mammary gland were less sensitive to glucose with regard to their reesterification rate of FFA than those of the greater

\section{Discussion}

An important finding from our experiments is that no spontaneous re-esterification of FFA was found in isolated human fat cells incubated in albumin-bicarbonate-buffer medium. This fact can be easily explained by the lack of glucose in the medium. It is well established that the re-esterification of FFA in adipose tissue only happens in the presence of alpha-
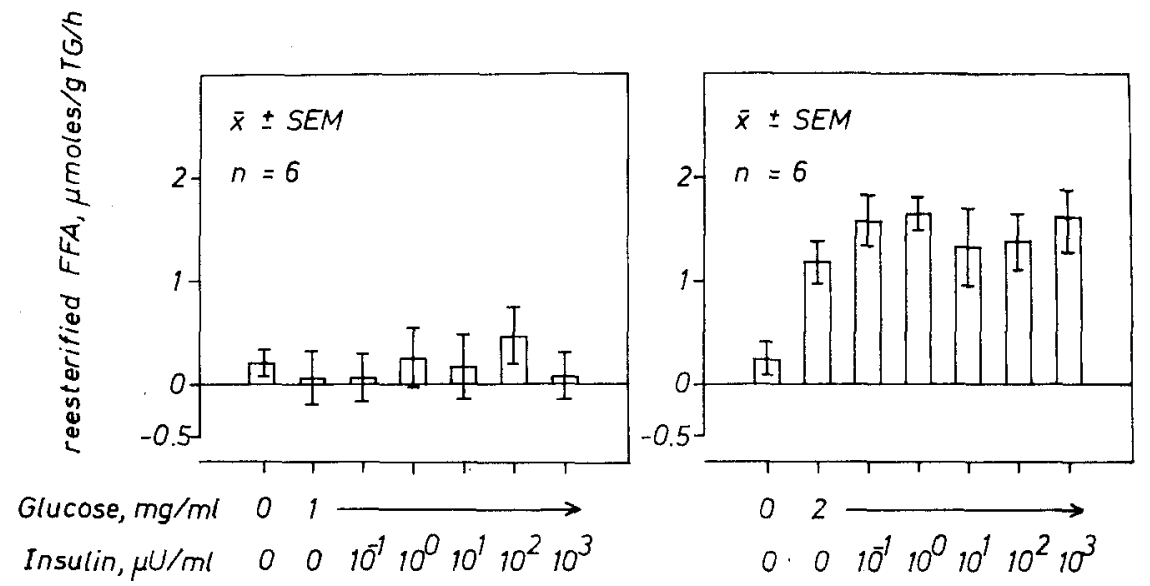

Fig. 3. Effects of glucose $(1$ and $2 \mathrm{mg} / \mathrm{ml})$ and glucose plus insulin $(0.1-1000 \mu \mathrm{U} / \mathrm{ml})$ on the re-esterification rate of FFA in isolated fat cells of the mammary gland. The mean values of the calculated re-esterification rate (single determinations) in 2 different groups of patients are indicated. The fat cell destruction index \pm SEM was for the cases in the first rectangle $0.79 \pm 0.10$ and in the second one $0.84 \pm 0.06$

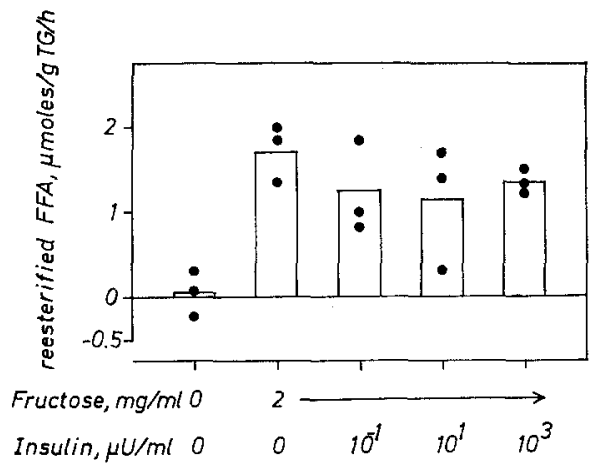

Fig. 4. Effect of fructose $(2 \mathrm{mg} / \mathrm{ml})$ and fructose plus insulin $(0.1,10$, and $1000 \mu \mathrm{U} / \mathrm{ml})$ on the re-esterification rate of FFA in 3 cases of isolated fat cells of the greater omentum. The average fat cell destruction index was 0.76

omentum (Fig. 3). Only $2 \mathrm{mg} / \mathrm{ml}$ glucose stimulated the re-esterification rate significantly $(t=3.00, p<$ 0.05). No effect of insulin was noted.

Like glucose, fructose was found to be a potent stimulator of the re-esterification rate of FFA in isolated omental fat cells (Fig. 4). A lack of insulin action on the re-esterification rate in the presence of fructose was also noted. The effects of glucose and fructose both at a concentration of $2 \mathrm{mg} / \mathrm{ml}$ did not differ significantly $(t=1.43, p>0.1)$. glycerophosphate, which is considered as the dominant fatty acid acceptor. The availability of alphaglycerophosphate as an intermediate product of carbohydrate metabolism $[7,30]$ depends on the presence of glycogen. Furthermore, it has been found previously, that alpha-glycerophosphate can hardly be formed by phosphorylation of released glycerol because of the very low activity of glycerokinase in human adipose tissue [21, 24]. In view of our results, it can finally be assumed that the tissue stores for alpha-glycerophosphate formation, i.e. glycogen, are non-existent or had been emptied during the isolation procedure of the fat cells.

In summary, the lack of basal re-esterification activity of FFA in isolated human fat cells can be accounted for the absence of the obligatory fatty acid acceptor alpha-glycerophosphate or its precursors. That insulin alone had no effect on the re-esterification rate, is explained by the absence of glucose.

The dose-dependent stimulating action of glucose alone, at physiological concentrations, on the reesterification rate of FFA in isolated human fat cells is well-established by the experiments. The difference in sensitivity to glucose between omental cells and fat cells of the mammary gland is compatible with other results $[15,5]$.

Insulin had no stimulating effect on the re-esterification rate in the presence of glucose. This can be 
interpreted, that, at least in isolated human fat cells, glucose enters the cell to form alpha-glycerophosphate without any need for insulin. The lack of effect of insulin on the re-esterification rate of FFA in the presence of glucose might be artefactual, viz. by possible destruction of insulin receptors during fat cell preparation, since an insulin effect on adipose tissue was obtained in vivo using the forearm technique [33]. In order to exclude such a possibility in our experiments, two other well-known insulin effects, the stimulation of incorporation of glucose into $\mathrm{CO}_{2}$ and lipids were sought. The incorporation of glucose-C into $\mathrm{CO}_{2}$ and lipids was stimulated by insulin in approximately the same order of magnitude as it was shown by previous studies $[15,9]$.

The reports of the effect of insulin on the utilization of glucose by human adipose tissue, with special reference to its incorporation into glyceride-glycerol, are contradictory. Goldrick and coworkers $[15,16,17]$ found a significant stimulating effect of insulin on the incorporation of labelled glucose into glycerideglycerol. This was confirmed by some other authors $[23,11,2,31]$, though in most cases unphysiologically high concentrations were employed, such as 10-100 $\mathrm{mU}$ of insulin per $\mathrm{ml}$ incubation medium. On the contrary, other authors found that insulin exerts only a slight effect on glyceride-glycerol formation from glucose [18, 12]. Similarly, Björntorp and Karlsson [4] described the insulin response of the incorporation of radioactivity from glucose into triglycerides in isolated human fat cells as small and varying, confirming earlier findings $[1,6]$. Likewise, no statistically significant insulin effect on lipogenesis from glucose could be demonstrated in human adipose tissue obtained by needle aspiration $[20,36]$. In human subcutaneous adipose tissue, insulin was reported to exert a stimulatory effect only on glycogen synthesis, but not on lipogenesis from glucose [9].

The lack of an effect of insulin on the re-esterification rate of FFA in our experiments cannot be interpreted as a complete absence of insulin action on glucose uptake by the human fat cell, because it could be shown that the incorporation of glucose-C into $\mathrm{CO}_{2}$ and lipids in the isolated fat cell preparation was stimulated by insulin.

Fructose was also found to stimulate the reesterification of FFA of the same order of magnitude as glucose. From this, it becomes evident, that human adipose tissue cells are also capable of manufacturing alpha-glycerophosphate from fructose.

\section{References}

1. Björntorp, P.: Studies on adipose tissue from obese patients with or without diabetes mellitus. II. Basal and insulin stimulated glucose metabolism. Acta med. scand. 179, 229-234 (1966)

2. Björntorp, P.: The effect of insulin in vitro on human adipose tissue from normal and diabetic subjects. Acta med. scand. 181, 389-402 (1967)
3. Björntorp, P.: Lipid mobilization from human subcutaneous adipose tissue in vitro. Acta med. scand. $182,717-726$ (1967)

4. Björntorp, P., Karlsson, M.: Triglyceride synthesis in human adipose tissue cells of different size. Europ. J. clin. Invest. 1, 112-117 (1970)

5. Björntorp, P., Karlsson, M., Hovden, A.: Quantitative aspects of lipolysis and re-esterification in human adipose tissue in vitro. Acta med. scand. 185, 89-97 (1969)

6. Björntorp, P., Martinsson, A.: Conversion of glucose ${ }^{14} \mathrm{C}$ into carbon dioxide and lipids in different specimens of human subcutaneous adipose tissue. Acta med. scand. 181, 359-366 (1967)

7. Cahill, G.F., Leboeuf, B., Renold, A.E.: Factors concerned with the regulation of fatty acid metabolism by adipose tissue. Amer. J. clin. Nutr. 8, 733-741 (1960)

8. Carlson, L.A.: Determination of serum triglycerides. J. Atheroscler. Res. 3, 334-336 (1963)

9. Davidson, M. B.: Effect of obesity on insulin sensitiv. ity of human adipose tissue. Diabetes 21, 6-12 (1972)

10. Duncombe, W. G.: The colorimetric micro-determination of long-chain fatty acids. Biochem. J. 88, 7-10 (1963)

11. Fessler, A., Beck, J.C.: The effect of insulin on the metabolism of human adipose tissue in vitro. Biochim. biophys. Acta (Amst.) 106, 199-201 (1965)

12. Fessler, A., Beck, J.C., Rubinstein, D.: Factors affecting lipid synthesis in human adipose tissue in vitro. Metabolism 16, 438-444 (1967)

13. Folch, J., Lees, M., Stanley, G.H.S. : A simple method for the isolation and purification of total lipids from animal tissues. J. biol. Chem. 226, 497-509 (1957)

14. Garland, P.B., Randle, P.J.: A rapid enzymatic assay for glycerol. Nature 196, 987-988 (1962)

15. Goldrick, R.B.: Effects of insulin on glucose metabolism in isolated human fat cells. J. Lipid. Res. 8, $581-588(1967)$

16. Goldrick, R.B., Ashley, B.C.E., Lloyd, Margaret, L.: Effects of prolonged incubation and cell concentration on lipogenesis from glucose in isolated human omental fat cells. J. Lipid. Res. 10, 253-258 (1969)

17. Goldrick, R.B., McLoughlin, G.M.: Lipolysis and lipogenesis from glucose in human fat cells of different sizes. J. clin. Invest. 49, 1213-1223 (1970)

18. Gries, F.A., Steinke, J.: Comparative effects of insulin on adipose tissue segments and isolated fat cells of rat and man. J. clin. Invest. 46, 1413-1421 (1967)

19. Herrera, E., Lamas, L. : Utilization of glycerol by rat adipose tissue in vitro. Biochem. J. 120, 433-434 (1970)

20. Hirsch, J., Goldrick, R. B. : Serial studies on the metabolism of human adipose tissue. I. Lipogenesis and free fatty acid uptake and release in small aspirated samples of subcutaneous fat. J. clin. Invest. 43, $1776-1792$ (1964)

21. Hood, B., Björntorp, P.: Studies on adipose tissue from obese patients with or without diabetes mellitus. III. Transformation of U-14 C-acetate and ${ }^{1-14} \mathrm{C}$-glycerol into carbon dioxide and lipid. Acta med. scand. 179, 349-353 (1966)

22. James, R.C., Burns, T.W., Chase, G.R.: Lipolysis of human adipose tissue cells: Influence of donor factors. J. Lab. clin. Med. 77, 254-266 (1971)

23. Kahlenberg, A., Kalant, N.: The effect of insulin on human adipose tissue. Canad. J. Biochem. 42, 1623$1635(1964)$

24. Koschinsky, T., Gries, F.A.: Glycerin-Kinase und Lipolyse des menschlichen Fettgewebes in Abhängigkeit vom relativen Körpergewicht. Hoppe-Seylers Z. physiol. Chem. 352, 430-432 (1971) 
25. Koschinsky, T., Gries, F.A., Herberg, L.: Glycerol kinase activity in isolated fat cells of $\mathrm{BHob}$ mice. Horm. Metab. Res. 2, 185-186 (1970)

26. Leboeuf, B.: Regulation of fatty acid esterification in adipose tissue incubated in vitro. In: Handbook of Physiology, Section 5: Adipose Tissue, pp. 385-391. Washington, D.C.: American Physiological Society 1965

27. Lisch, H..J.: Unpublished observations

28. Lisch, H.-J., Sailer, S., Sandhofer, F., Braunsteiner, H.: Untersuchungen an isolerten menschlichen Fett. zellen verschiedener Fettgewebsregionen. I. Beziehungen zwischen relativem Körpergewicht und Zellvolumen. Klin. Wschr. 48, 1349-1353 (1970)

29. Lisch, H.-J., Sailer, S., Sandhofer, F., Tschikof, R., Braunsteiner, $H$.: The action of insulin and glucose on lipolysis in isolated human fat cells. Horm. Metab. Res. 1973 (in press)

30. Lynn, W.S., MacLeod, R.M., Brown, R.H.: Effects of epinephrine, insulin, and corticotrophin on the metabolism of rat adipose tissue. J. biol. Chem. 235, 1904-1911 (1960)

31. Mellati, A.M., Beck, J.C., Dupre, J., Rubinstein, D.: Conversion of glucose to lipid by human adipose tissue in vitro. Metabolism 19, 988-994 (1970)

32. Oelz, O.: Personal report (1970)

33. Rabinowitz, D., Zierler, K.L.: Forearm metabolism in obesity and its response to intra-arterial insulin.
Characterization of insulin resistance and evidence for adaptive hyperinsulinism. J. clin. Invest. 41, 21732181 (1962)

34. Robinson, J., Newsholme, E.A.: Glycerol kinase activities in rat heart and adipose tissue. Biochem. J. $104,2 \mathrm{c}-4 \mathrm{c}(1967)$

35. Rodbell, M. : Metabolism of isolated fat cells. I. Effects of hormones on glucose metabolism and lipolysis. J. biol. Chem. 239, 375-380 (1964)

36. Salans, L.B., Knittle, J.L., Hirsch, J.: The role of adipose cell size and adipose tissue insulin sensitivity in the carbohydrate intolerance of human obesity. $\mathbf{J}$. clin. Invest. 47, 153-165 (1968)

37. Society of Actuaries (Ed.): Build and blood pressure study, Vol. 1, Chicago 1959. Cit. Documenta Geigy, Wissenschaftliche Tabellen, 7. Auflage, J.R. Geigy A.G., Pharmazeutische Abteilung, Basel

38. Vaughan, M.: The metabolism of adipose tissue in vitro. J. Lipid. Res. 2, 293-316 (1961)

39. Vaughan, M.: The production and release of glycerol by adipose tissue incubated in vitro. J. biol. Chem. 237, $3354-3358$ (1962)

Dr. H. -J. Lisch

Med. Univ.-Klinik

A-6020 Innsbruck

Anichstraße 35

Austria 